\title{
Synthesis and characterization of short sisal fibre polyester composites
}

\author{
NEHA UPPAL, ASOKAN PAPPU, RAVI PATIDAR and V SORNA GOWRI* \\ Advanced Materials and Processes Research Institute, CSIR, Bhopal 4620646, India \\ *Author for correspondence (gowrisorna@yahoo.com)
}

MS received 4 January 2018; accepted 19 January 2019; published online 25 April 2019

\begin{abstract}
Natural fibres have the potential to replace synthetic fibres for making polymer composites because of their good engineering properties. Sisal fibres obtained from the leaves of the sisal plant exhibit high strength among various other natural fibres, but have not been yet fully explored. Nevertheless, the impact of sisal fibre in polymer composites depends on sisal fibre extraction process, characteristic of fibre, fibre binder ratios, synthesizing technique, etc. In the present study, a detailed experimental protocol was conducted for sisal cultivation, fibre extraction, processing and development of composite boards/panels and assessed the impact of incorporation of chopped strand sisal fibre mat on the mechanical behaviour of polyester composites. The results revealed that the diameter of sisal fibre harvested after 5 years of its cultivation varied from 275 to $475 \mu \mathrm{m}$ with a tensile strength of 121-337 MPa; tensile modulus of 2.59-10.47 GPa; elongation at break varied from 3.37 to $10.86 \%$. It is imperative to note that the mechanical properties of sisal composites significantly improved with the incorporation of chopped strand sisal fibre mat (preform). The tensile, flexural and impact strengths of composites developed using chopped short sisal fibre mat (preform) were $45.87 \pm 3.2,102.29 \pm 9,33,954 \pm 5288 \mathrm{~J} \mathrm{~m}^{-2}$, respectively. The findings of the study revealed the effectiveness of sisal fibre as reinforcing materials in polyester composites for use in building construction products and automotive applications.
\end{abstract}

Keywords. Sisal fibre; polyester composites; mechanical strength; morphological properties; thermal analysis.

\section{Introduction}

Composites are generally made from glass, carbon and other synthetic fibres and they are not ecofriendly and not biodegradable. Growing environmental concerns have led to the use of renewable natural materials for the design and development of new components/products and now the use of natural fibres has made new paradigm in manufacturing the composite materials. The main advantages of using natural fibre in composite materials are (i) simple processing, (ii) lower specific weight, (iii) good acoustic properties and mechanical strength. Natural fibres are rich in cellulose and biodegradable and are not yet fully exploited for their use. Natural fibres have great utility for engineering applications and are also available in most of the countries. These natural fibres can be substituted for synthetic fibres in various consumer composite products especially for structural applications.

Natural fibres have emerged as a renewable and cheaper substitute for synthetic fibres, such as glass and carbon, which are used as reinforcement in making structural components. The high cost of the synthetic fibres has limited their application. Natural fibres are relatively inexpensive and an easily available renewable resource. Many research studies have been reported on natural fibre-reinforced plastic composites and natural polymers with excellent mechanical properties, which can be used as matrix in such composites [1-10]. Sisaland jute-fibre-reinforced composites have been studied by many researchers [11-15].

Sisal (Agave sisalana) is one of the natural fibre-yielding plants, which belongs to the family Asparagaceae. It is a hardy plant, which grows in arid and semi-arid tropics with moderate humidity in almost all types of soils, including wasteland conservation. From all over the world, about 4.5 million tons of sisal fibres have been produced every year. Brazil and Mexico are the two main sisal fibre-producing countries. However, currently sisal plant has been cultivated in many parts of Asia, including China, Indonesia and India. Sisal fibre is a renewable/replenishable resource. Sisal leafs are generally ready for harvest after 3 years from planting. A typical sisal plant produces 200-250 commercially usable leaves in its life time. The sisal plant with productive fibre-bearing leaves has potential to yield fibre continuously for about 10 years in its life span of about 15 years. Sisal plantation in India yield about 2.5 ton dry fibre per year per hectare. Sisal fibre has excellent properties for engineering applications with high strength-toweight ratio. Currently, sisal fibres are being used in making handicrafts, rope, textile, mats, paper, fibre composites, vermi compost, bio-energy, pharmaceuticals, automotives, building materials, packaging and geo-textile applications.

Composites made up of sisal fibres are eco-friendly and do not consume much of energy for their production. During 
synthesis, fibre length, orientation, concentration, dispersion, aspect ratios and selection of matrix are to be considered to attain good strength. Inorganic and synthetic fibres have several disadvantages, like their non-biodegradability, the abrasion in processing equipments, high cost and density and the health problems caused to workers during processing and handling. The advantages of using sisal fibre over synthetic fibre are low cost, low density, acceptable specific strength, easy extraction and biodegradability. Other benefits of sisal fibre include moderate moisture regain and good thermal and acoustic insulation properties [16-18].

The quality of sisal fibre, in terms of its brightness, colour, larger staple length are better than that of other natural fibres like jute, sun hemp fibre, coir, banana and pineapple fibres, etc. Further, surface treatments enable sisal fibres as reinforcement in polymer matrix composites. Mechanical strength of sisal fibre is comparable with other natural fibres [19-22].

Sisal fibre is extracted by retting and biodegradation process involving microbial decomposition of sisal leaves, which separates the fibre from pith. The other methods of fibre extraction are chemical treatment and mechanical extraction using Raspador machine.

It is reported that sisal fibre consists of $43-80 \%$ cellulose, $7-10 \%$ hemicellulose and $7.5 \%$ lignin [23,24]. The natural fibre-reinforced polymer composites (NFRPC) are conventionally made up of plastic resins as the binder matrix and natural fibre as the reinforcing material.

Considerable work has been carried out by various researchers on natural fibre composites with special reference to the identification and classification of fibres, surface treatments, interfacial bonding between fibre and matrix, composite characteristics, environmental effects and also explored the possible application [25-31].

Natural fibre has been used as a reinforcing medium in the composite to improve the quality both in hydrophobicthermoplastic or hydrophilic-thermoset composites [26,32, 33]. Lignocellulosic fibres have showed significant utility in the composites due to various environmental concerns [34]. In fact, environment legislation as well as consumer demands are all increasing the manufacturing requirements of these materials and final products to consider the virtual impact of the product at all stages of their life cycle. The demand of such materials especially for the glass fibre substitute in the automotive industries have attracted the attention of environmental protagonist [35,36].

The advantages of using natural fibre in composite materials are process friendly, lower in specific weight and exhibits thermal and acoustic insulating properties [37]. Nevertheless, the shortcoming with the natural fibre in composites are variation in the quality, limitation in processing temperature, strength properties, durability, poor fire resistance and supply chain.

Sisal fibre has not been fully utilized except making rope and some handicraft items. Very limited research outcome is reported on the effectiveness of sisal fibre in polymer composites. Besides, no technological options are available for
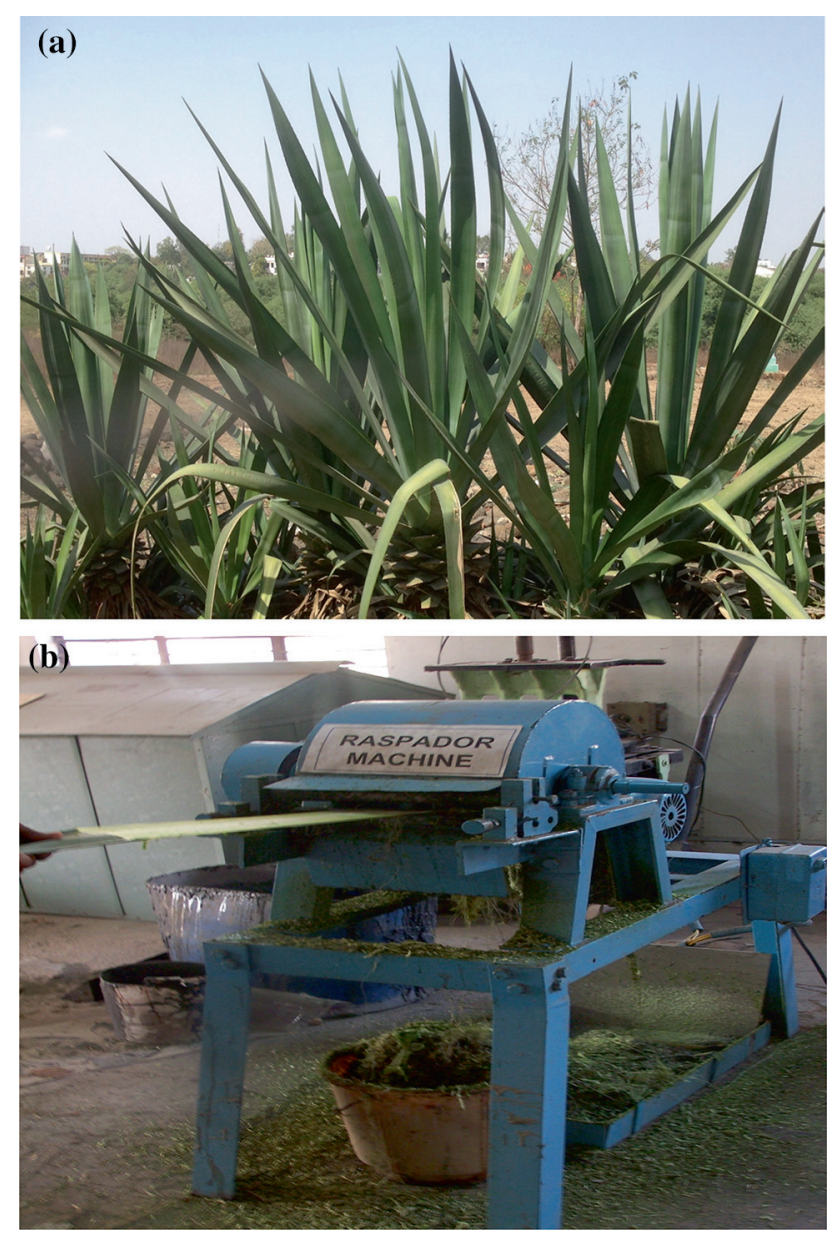

Figure 1. (a) A fully grown up sisal plant after five years of plantation. (b) Sisal fibre mechanical extraction process.

making yarn from sisal fibre for textile applications. The present paper deals with the research outcome on the potential and influence of short sisal fibre in developing polyester composites in comparison with sisal textile composites developed earlier [38].

\section{Materials and methods}

Sisal plants were cultivated on black cotton soil at the premises of the Advanced Materials and Processes Research Institute (AMPRI), Bhopal, Central India. The leaves of these sisal plants were cut for fibre extraction. Figure 1 shows the sisal plant after five years of growth. The average dimensions of the sisal leaves was $1.4 \pm 0.84 \mathrm{~m}$ in height (length), $5-10 \mathrm{~cm}$ wide at the base, and $10-16 \mathrm{~cm}$ across at the widest portion, terminating in a sharp spine.

\subsection{Sisal fibre extraction and processing}

Figure 1a shows a fully grown sisal plant after five years of planting at AMPRI, Bhopal, India. The sisal fibre was extracted by employing mechanical extraction using 


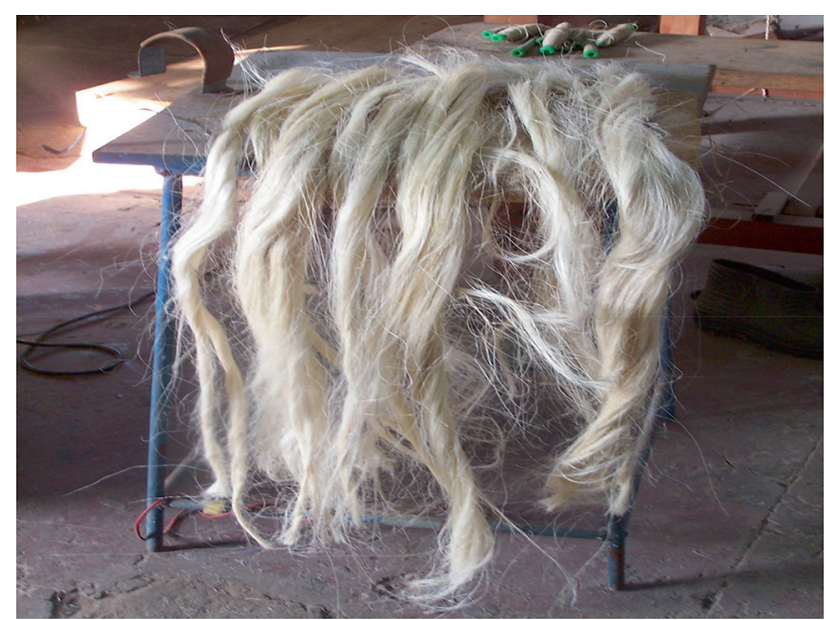

Figure 2. Processed sisal fibre used for making composites.

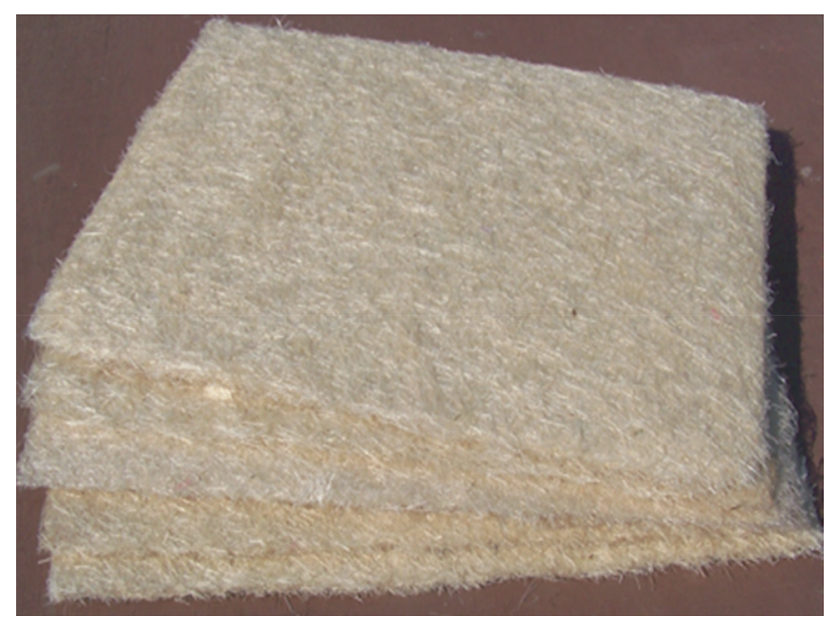

Figure 3. Sisal preform madeup of chopped sisal fibre length of $5 \mathrm{~cm}$.

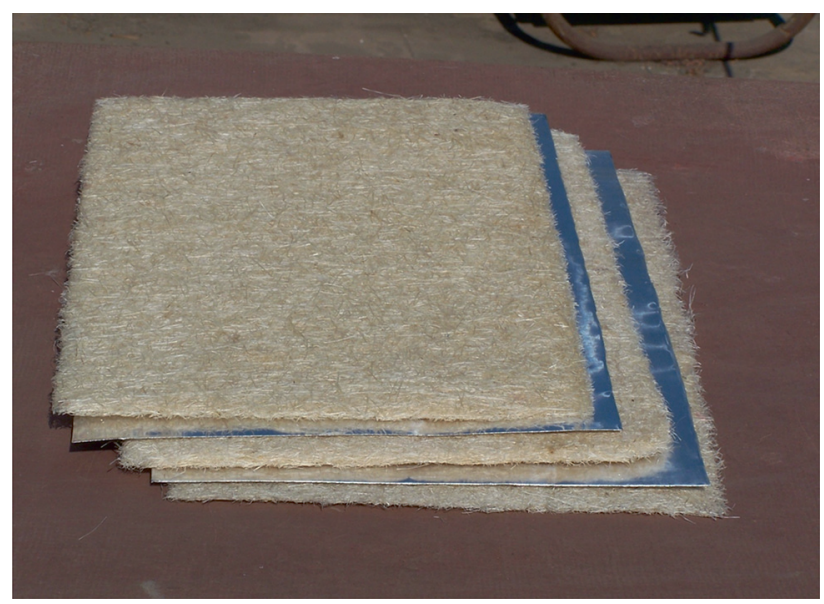

Figure 4. Sisal fibre polyester composites using chopped sisal fibre.

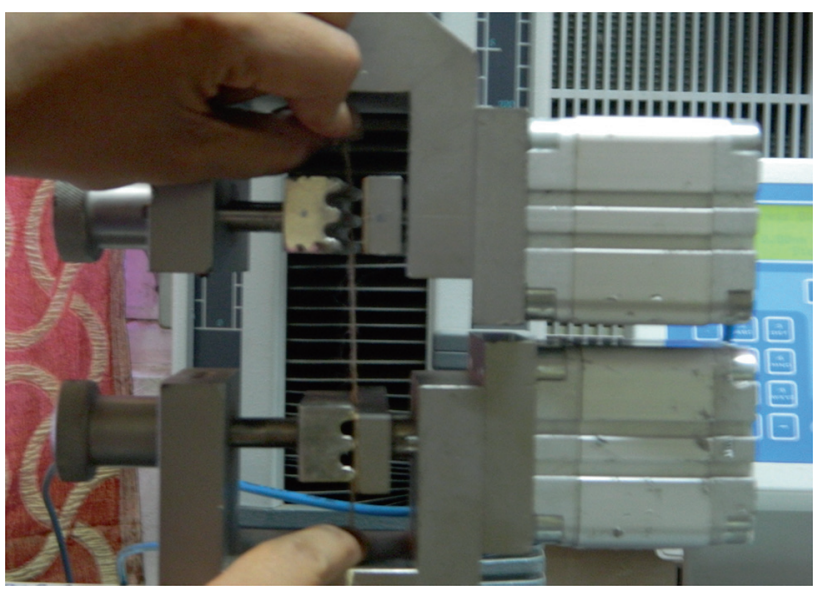

Figure 5. Testing tensile strength of sisal fibre.

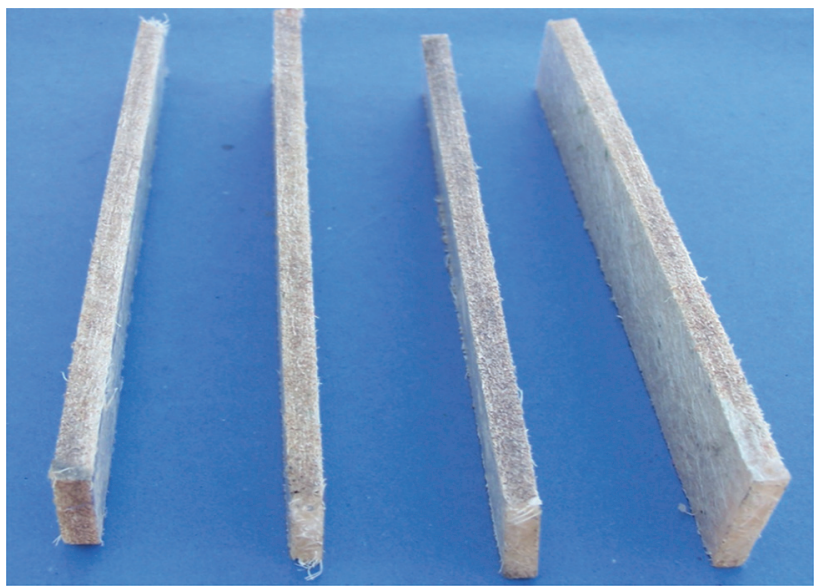

Figure 6. Samples of sisal preform composites made up of chopped sisal fibre length of $5 \mathrm{~cm}$ used for testing tensile strength and impact studies.

Raspador machine, which did not deteriorate the quality of the fibre. The process of extraction is highly efficient as the time required for a single leaf was about $60 \mathrm{~s}$. Figure $1 \mathrm{~b}$ shows the sisal fibre extraction process using Raspador machine at AMPRI, Bhopal, India.

The extracted sisal fibres were dried under natural environment conditions for over a period of $8 \mathrm{~h}$. These fibres were initially processed by washing in warm water and sun-dried for $4 \mathrm{~h}$ under natural conditions (temperature $32 \pm 2{ }^{\circ} \mathrm{C}$ ). The dried sisal fibres were combed and used for making composites (figure 2).

\subsection{Fabrications of short sisal fibre polyester composites}

For the synthesis of composites, sisal preforms were made using chopped sisal fibres of $5 \mathrm{~cm}$ length (figure 3 ).

Composites were synthesized using these preforms. Unsaturated polyester resin (polylite PO 9123) along with cobalt naphthanate (1.5 vol\%) as accelerator and methyl ethyl ketone 
Table 1. Mechanical properties of sisal fibre.

\begin{tabular}{lccccc}
\hline & & & Tensile \\
Number & Diameter $(\mu \mathrm{m})$ & $\begin{array}{c}\text { Load at maximum } \\
\text { load }(\mathrm{N})\end{array}$ & $\begin{array}{c}\text { Youngth } \\
\text { modulus } \\
(\mathrm{MPa})\end{array}$ & $\begin{array}{c}\text { Percentage total } \\
\text { elongation at } \\
\text { fracture }(\%)\end{array}$ \\
\hline 1 & 378 & 17.14 & 152.75 & 4.30 & 5.02 \\
2 & 448 & 24.31 & 154.27 & 3.59 & 6.69 \\
3 & 275 & 16.18 & 272.55 & 6.42 & 8.06 \\
4 & 294 & 13.47 & 198.49 & 6.55 & 4.22 \\
5 & 462 & 23.22 & 138.56 & 2.96 & 6.52 \\
6 & 293 & 10.75 & 159.43 & 5.30 & 3.37 \\
7 & 278 & 14.00 & 230.67 & 6.55 & 4.49 \\
8 & 475 & 28.51 & 160.91 & 3.47 & 10.86 \\
9 & 283 & 14.12 & 224.53 & 6.86 & 4.43 \\
10 & 253 & 16.94 & 336.96 & 10.47 & 5.39 \\
11 & 325 & 18.75 & 226.11 & 5.56 & 7.17 \\
12 & 287 & 13.89 & 214.72 & 7.72 & 4.40 \\
13 & 370 & 15.42 & 143.48 & 3.83 & 5.32 \\
14 & 288 & 9.71 & 149.03 & 6.21 & 3.66 \\
15 & 312 & 15.12 & 197.87 & 5.51 & 4.89 \\
16 & 451 & 19.33 & 121.05 & 2.59 & 5.29 \\
17 & 432 & 19.98 & 136.36 & 3.26 & 5.73 \\
18 & 458 & 27.97 & 169.80 & 4.35 & 24.52 \\
19 & 424 & 25.12 & 177.96 & 4.72 & 5.31 \\
20 & 427 & 25.29 & 176.67 & 3.76 & 6.10 \\
Average & 360.65 & 18.46 & 187.11 & 5.20 & 6.57 \\
SD & 78.69 & 5.59 & 52.53 & 1.92 & 4.55 \\
\hline & & & & &
\end{tabular}

peroxide (MEKP) as catalyst (2 vol\%) was used for the preparation of composites under compression moulding system with constant pressure of $1 \mathrm{MPa}$ at room temperature of $32 \pm 2^{\circ} \mathrm{C}$. The composites were set for $2 \mathrm{~h}$; however, they were cured for $24 \mathrm{~h}$ at $36 \pm 2{ }^{\circ} \mathrm{C}$ (figure 4). The dimension of mild steel mould was $32 \times 32 \mathrm{~cm}$, which has a provision of making the desired thickness varying from 3 to $19 \mathrm{~mm}$.

\subsection{Characterization of sisal fibre}

Tensile strength of the processed sisal fibre was tested as per ASTM D-1517 using fibre testing machine, universal testing machine (UTM), $5 \mathrm{kN}$ capacity (LRX Plus, Lloyd, UK). For testing sisal fibre, $50 \mathrm{~N}$ load cell was used with cross head speed of $5 \mathrm{~mm} \mathrm{~min}^{-1}$ at $50 \mathrm{~mm}$ gauge length (figure 5).

\subsection{Characterization of sisal fibre composites}

Preparation of flat composite panels for specimen preparation was carried out as per the ASTM (D-5678-D5678M-95R02). Instructions from ASTM D-256 was followed to study the impact strength of chopped sisal fibre polyester composites using Impact tester (with notcher), IT504, Tinius Olsen, UK. Instructions from ASTM D-790 and ASTM-D-3039 were followed to determine the flexural strength and tensile strength of polyester composite materials using UTM $(5 \mathrm{kN})$, LRX Plus, Lloyd, UK. The flexural strength was tested using $5 \mathrm{kN}$ load cell with stress speed of $1.62 \mathrm{~mm} \mathrm{~min}^{-1}$. The width of the sample was $12.72 \mathrm{~mm}$ and thickness was $3.18 \mathrm{~mm}$. The area of the test specimen was $40.45 \mathrm{~mm}^{2}$. Figure 6 shows samples of short sisal fibre composites made of chopped sisal fibres of $5 \mathrm{~cm}$ used for testing tensile and impact strength of the composites.

\section{Results and discussion}

\subsection{Sisal leaf and sisal fibre characterization}

The average diameter of harvested sisal leaf used in this work was $360.65 \pm 78.69 \mu \mathrm{m}$. The tensile properties of sisal fibres are reported in table 1 . The average tensile strength of sisal fibre was found to be $187 \pm 52.53 \mathrm{MPa}$ and with a tensile modulus of $5.20 \pm 1.92 \mathrm{GPa}$. The recorded minimum/maximum tensile strengths were 121.05 and $336.96 \mathrm{MPa}$ and the resulting tensile moduli were 2.59 and $10.47 \mathrm{GPa}$, respectively. It is evident from the present study that the diameter of single sisal fibre varied from $275 \mu \mathrm{m}$ to as high as $475 \mu \mathrm{m}$ and the mean diameter was $360.65 \mu \mathrm{m}$. The interpretation of scanning electron microscope (SEM) studies revealed that each fibre consists of bundle of fibrils and microfibrils where the shape, size and diameter of fibres can be seen from SEM microstructure (figure $7 \mathrm{a}$ and $\mathrm{b}$ ). 

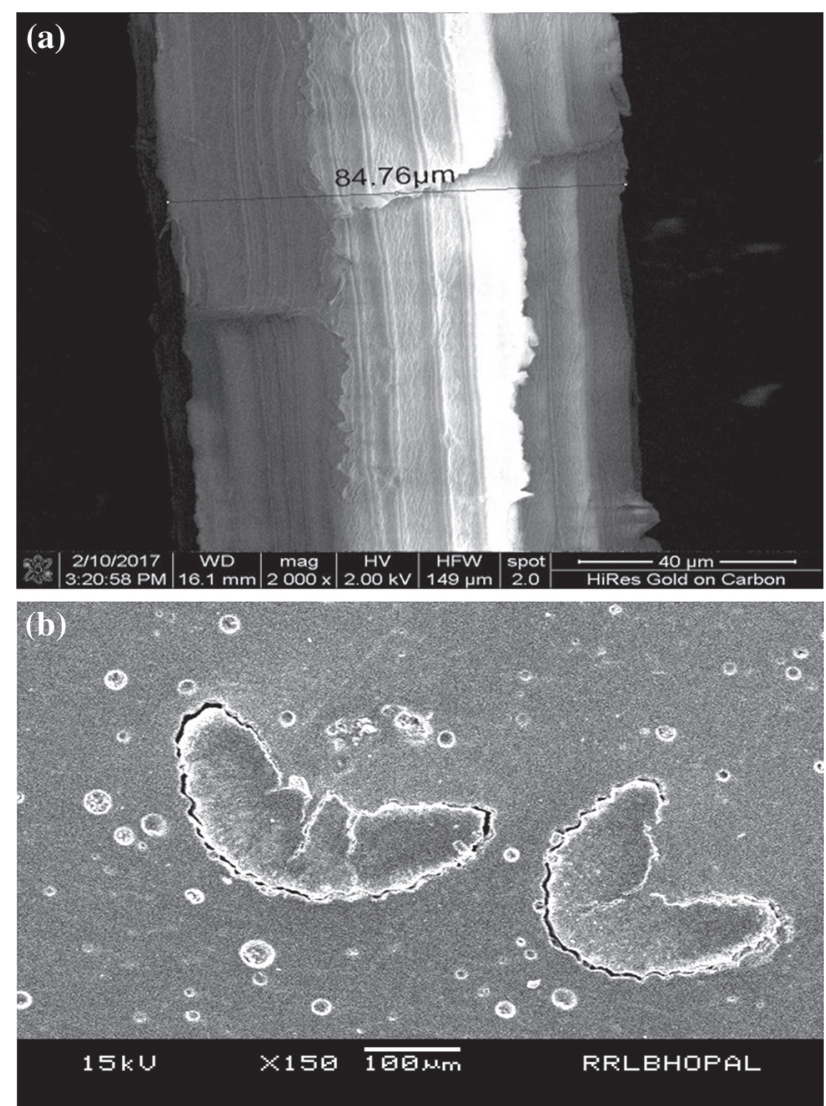

Figure 7. (a) SEM microstructure of sisal fibre showing diameter, (b) cross-section (length of the scale bar: $40 \mu \mathrm{m}$ ). (b) SEM microstructure of sisal fibre showing cross-section (length of the scale bar: $100 \mu \mathrm{m}$ ).

\subsection{Characterization of short sisal fibre polyester composites}

The mechanical, microstructural and thermal properties of the composites are discussed as below.
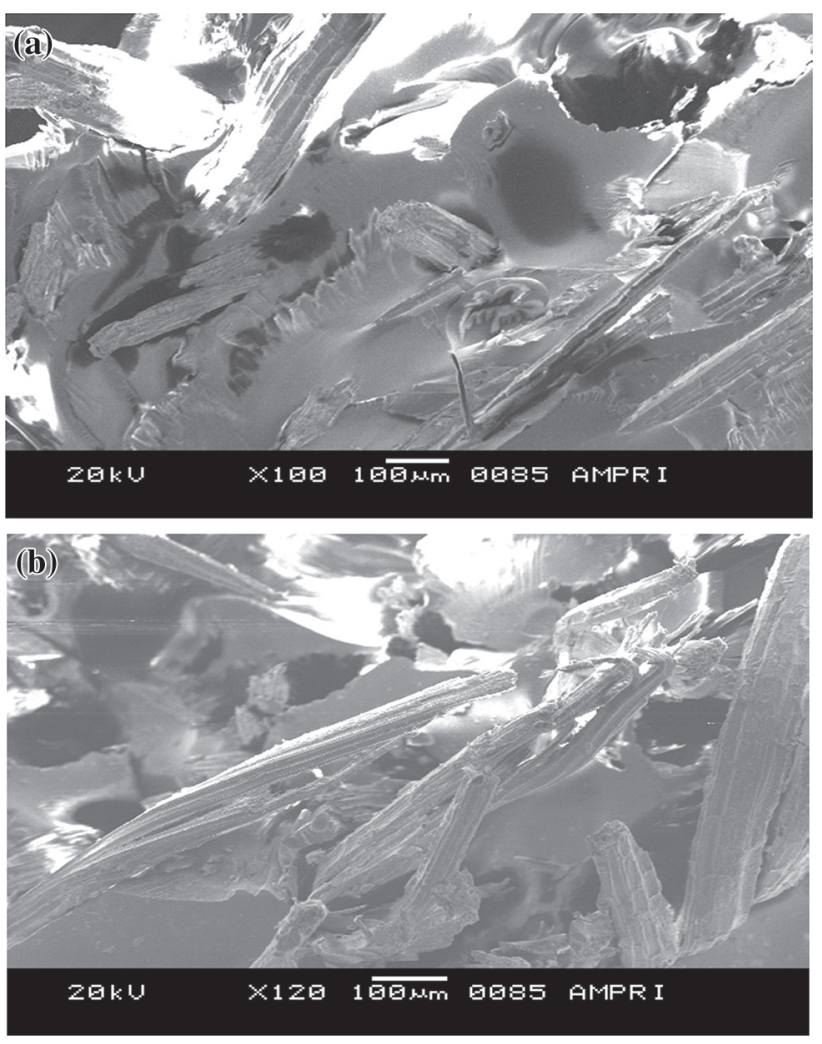

Figure 8. (a) SEM of impact fracture surface of sisal polyester composite (length of the scale bar: $100 \mu \mathrm{m}$ ). (b) SEM micrograph of fracture surface of tensile strength-tested sisal fibre composites (length of the scale bar: $100 \mu \mathrm{m}$ ).

3.2a Mechanical properties: The tensile strength and tensile modulus of chopped short sisal fibre composites are shown in table 2 . The results from the present study show that the tensile strength and modulus of chopped fibre composites are $45.87 \pm 3.02 \mathrm{MPa}$ and $0.966 \pm 0.524 \mathrm{GPa}$, respectively. The tensile strength and modulus of textile composites were $23.83 \pm 0.9 \mathrm{MPa}$ and $1.91 \pm 0.285 \mathrm{GPa}$, respectively, as reported earlier [38].

Table 2. Mechanical properties of sisal composites with chopped fibre.

\begin{tabular}{|c|c|c|c|c|c|c|c|c|}
\hline \multirow[b]{2}{*}{ Number } & \multicolumn{3}{|c|}{ Flexural properties } & \multicolumn{3}{|c|}{ Tensile properties } & \multirow[b]{2}{*}{ Elongation (\%) } & \multirow{2}{*}{$\begin{array}{c}\text { Impact } \\
\text { strength } \\
\left(\mathrm{J} \mathrm{m}^{-2}\right)\end{array}$} \\
\hline & $\begin{array}{l}\text { Maximum load } \\
\text { at failure }(\mathrm{N})\end{array}$ & $\begin{array}{c}\text { Flexural } \\
\text { strength (MPa) }\end{array}$ & $\begin{array}{c}\text { Flexural } \\
\text { modulus }(\mathrm{GPa})\end{array}$ & $\begin{array}{c}\text { Maximum load } \\
\text { at break }(\mathrm{kN})\end{array}$ & $\begin{array}{c}\text { Tensile strength } \\
(\mathrm{MPa})\end{array}$ & $\begin{array}{c}\text { Tensile } \\
\text { modulus (GPa) }\end{array}$ & & \\
\hline 1 & 200.46 & 116.88 & 5305.4 & 1.7426 & 42.153 & 622.45 & 9.27 & 33900 \\
\hline 2 & 182.53 & 106.43 & 5450.6 & 1.7096 & 41.354 & 615.96 & 9.55 & 27800 \\
\hline 3 & 157.48 & 91.824 & 3973.5 & 1.8437 & 44.599 & 684.97 & 8.94 & 44900 \\
\hline 4 & 184.90 & 107.81 & 4966.0 & 2.0313 & 49.136 & 665.45 & 9.96 & 32600 \\
\hline 5 & 164.20 & 95.743 & 4745.0 & 1.8728 & 45.302 & 708.47 & 9.52 & 32700 \\
\hline 6 & 177.51 & 103.50 & 5524.3 & 2.0221 & 48.914 & 1709.1 & 3.90 & 34380 \\
\hline 7 & 160.94 & 93.838 & 4821.4 & 2.0523 & 49.645 & 1755.8 & 3.95 & 31400 \\
\hline Mean & 175.43 & 102.29 & 4969.46 & 1.91 & 45.87 & 966.03 & 7.88 & 33954.29 \\
\hline SD & 15.43 & 9.00 & 534.86 & 0.15 & 3.42 & 524.75 & 2.71 & 5288.35 \\
\hline
\end{tabular}




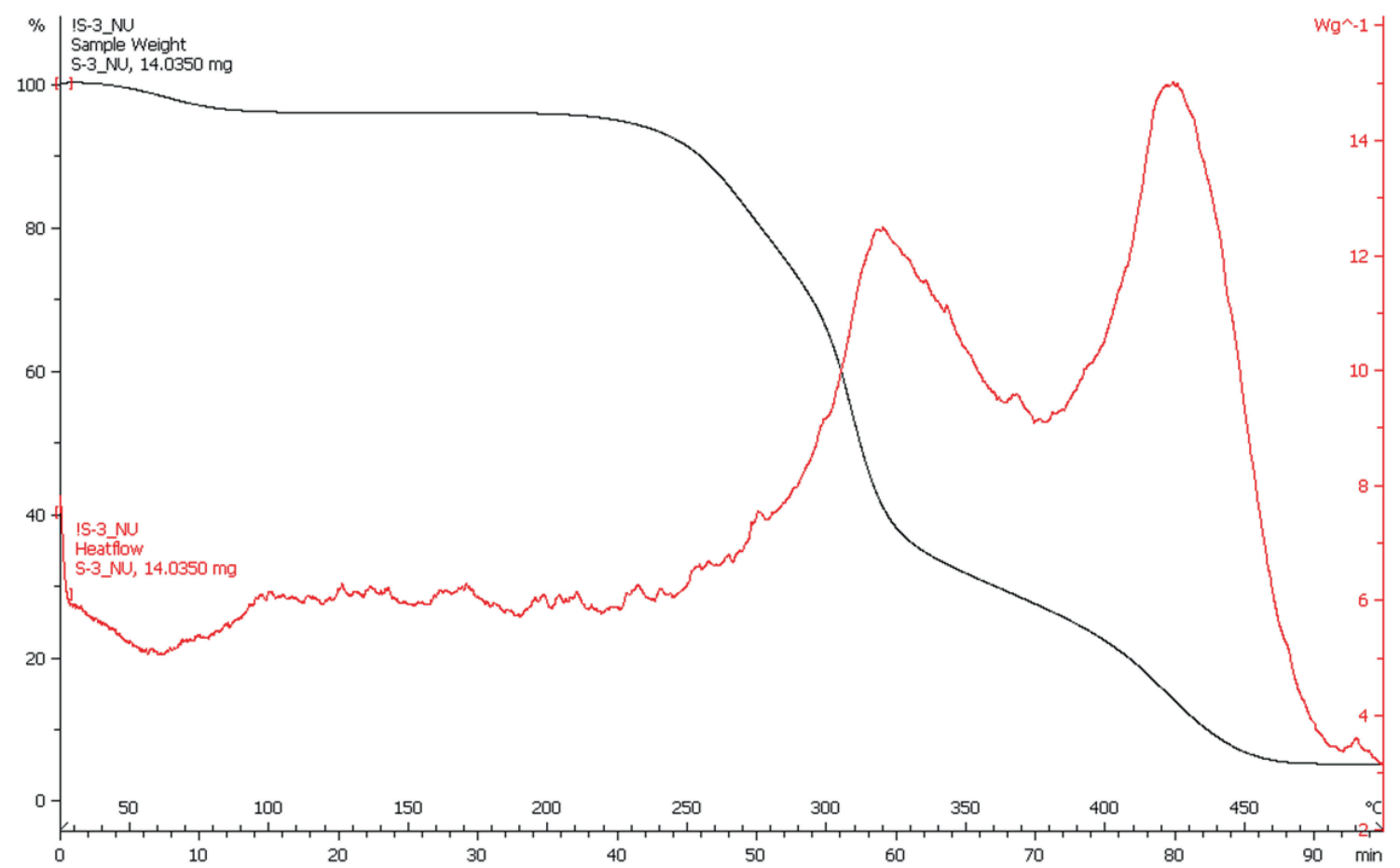

Figure 9. Thermal properties (TGA/DSC curve).

The present study shows the chopped sisal fibre composites have better tensile strength than the sisal textile composites as reported in our earlier work.

The flexural strength and flexural modulus of chopped short sisal fibre composites are 102.29 $\pm 9 \mathrm{MPa}$ and $4.969 \pm$ $0.534 \mathrm{GPa}$, respectively. The flexural strength and flexural modulus of sisal textile composites were $95.00 \pm$ $22.85 \mathrm{MPa}$ and $4.408 \pm 0.460 \mathrm{GPa}$, respectively. The flexural strength of chopped fibre composites is higher than the textile composites [29]. It may be due to the high level of twist that limits the mechanical properties of the final composites by reducing the impregnation of the resin and fracture of the fibre cell wall at high level twisting in the case of sisal textile composites. Smaller discontinuous fibres with high level twisting increase the degree of misalignment and this could account for some reduced compatibility and reduced strength in sisal textile composites.

Impact strength of short sisal fibre-reinforced composites is $33.954 \pm 5.2 \mathrm{~kJ} \mathrm{~m}^{-2}$ and that of textile composite is $20.036 \mathrm{~kJ} \mathrm{~m}^{-2}$ [38]. Here, the impact strength of chopped fibre sisal composites is better than textile composites. Dry yarn leads to lower bonding between yarns and resin leading to delamination and lowering of the mechanical properties of sisal textile composites. Our findings are similar to the results of Idicula et al [39].

Earlier studies showed that textile fibre composites show better mechanical properties than short fibre composites [40]. In the present study, there was slight improvement in the tensile strength of short sisal fibre composites when compared to sisal composites reported by Athiyayamani et al [41]. Their work use traditional methods of fibre extraction by retting process and microbial biodegradation process, which may involve decomposition of sisal leaves to separate the fibres from the pith. In such processes, there is a possibility of fibre degradation which could affect the fibre quality. The present research shows the mechanical extraction processes by using Raspador machine which gives better mechanical properties.

3.2b Microstructure: SEM micrograph of the fracture surface of textile composites shows the interfacial cohesion between fibres and resin surfaces which appears to be not so strong [38]. In chopped short fibre composites, it was noted that the sisal fibres were tightly attached with polymer matrix, which suggested that the interfacial bonding between sisal fibre and the polymer is better than textile composites, which results in the improvement in the adhesion between fibre surface and matrix and this good adhesion leads to an increase in mechanical properties of chopped fibre-reinforced composites, wherein textile composites, high level of twisting of fibres lead to poor adhesion between fibre and matrix which lead to inferior mechanical properties of textile composites when compared to chopped short sisal fibre composites (figure 8a and b).

Sisal fibres are very hard and exhibit poor crimp properties and it is evident from earlier work which reported that yet no machine is available for making fine sisal yearns for textiles. 
3.2c Thermal properties of composites: The differential scanning calorimetric (DSC) and first derivative of the thermo gravimetric analysis (TGA) with respect to time (derivative thermo gravimetric i.e., DTG) curves obtained from fresh samples during the heating ramp of $5^{\circ} \mathrm{C} \mathrm{min}^{-1}$ are shown in figure 9. The thermal analysis of chopped short fibre composites revealed that the main mass loss process ends at around $255.99-312.15^{\circ} \mathrm{C}$. The decomposition of cellulose and hemicelluloses started around $255^{\circ} \mathrm{C}$. The decomposition was fast above this temperature and completed around $463.26^{\circ} \mathrm{C}$. A total weight loss of the composites was observed in the decomposition of sisal polyester composites. A similar trend was observed with our earlier work on sisal textile composites and research studies on nanoclay-filled polymer composites by Ganguly et al $[38,42]$.

\section{Conclusions}

From the results presented above, it can be concluded that composites developed using chopped strand short sisal fibre have mechanical properties like tensile strength, flexural strength and impact strength higher than those of sisal textile composites. This may be due to the following reasons.

In contradiction to earlier work based on sisal textile composites, our present studies show short fibre composites that have better mechanical properties, which may be due to the twisted yarns in textile composites that become more compact making it difficult for the resin to penetrate into the yarn. In the case of sisal textile composites, high level of twist limits the mechanical properties of the final composites by reducing the impregnation of the resin and fracture of the fibre cell wall at high level twisting. Smaller discontinuous fibres with high level twisting increase the degree of misalignment and this could account for some reduced compatibility and reduced strength.

Finally, the age of the fibre also contributes to the properties of the composites. In the present studies, short fibre composites are made of chopped sisal fibres immediately after extraction but in the case of sisal textile composites, the yarns used are three-year-old fibres. It may be concluded that the ageing of the fibres also caused inferior mechanical properties of the composites when compared to fresh chopped sisal fibre composites.

The findings confirm that the high potential of short sisal fibre composites to enhance the tensile properties of polyester composites over the sisal textile polyester composites.

\section{References}

[1] Jindal U C 1986 J. Compos. Mater. 201

[2] Shah A N and Lakkad S C 1981 Fiber. Sci. Technol. 1541

[3] Jain S, Jindal U C and Kumar R 1993 J. Mater. Sci. 274598

[4] Roe P J and Ansell M P 1985 J. Mater. Sci. 204015

[5] Singh B, Gupta M and Verma A 1996 Polym. Compos. 176
[6] Mukherjea R N, Pal S K and Sanyal S K 1983 J. Appl. Polym. Sci. 283029

[7] White N M and Ansell M P 1983 J. Mater. Sci. 181549

[8] Rherrera-Franco P J and Valadez-González A 2005 Compos. B Eng. A 36597

[9] Shin F G and Yipp M W 1989 J. Mater. Sci. 243483

[10] Ganguly S, Mondal S, Das P, Bhawal P, Maity P P, Ghosh S et al 2018 Int. J. Biol. Macromol. 111983

[11] Barkakaty B C and Robson A 1979 J. Appl. Polym. Sci. 24 269

[12] Joseph K, Thomas S and Pavithran C 1995 Compos. Sci. Technol. 5399

[13] Bisanda E T N and Ansell M P 1992 J. Mater. Sci. 271690

[14] Chang H W, Smith R P, Li S K and Neumann A W (eds) 1985 Molecular characterization of composite interfaces (New York: Plenum Press) p 413

[15] Mohanty A K, Misra M and Hinrichson G 2000 Macromol. Mater. Eng. 276313

[16] Mohanty A K, Misra M and Drzal L T 2001 Compos. Interfaces $\mathbf{8} 313$

[17] Mishra S, Mohanty A K, Drzal L T, Misra M, Parija S, Nayak S K et al 2005 Compos. Sci. Technol. 631377

[18] Mohanty A K and Misra M 1995 Polym. Plast. Technol. Eng. Res. 34729

[19] Chandra Mohan D and Marimuthu K 2011 IJRRAS 8194

[20] Das P K, Nag D, Debnath S and Nayak L K 2010 Indian J. Tradit. Know. 9386

[21] Ortega Z, Morón M, Monzón M D, Badalló P and Pa R 2016 Materials 9370

[22] Asokan P, Patil V, Jain S, Mahindrakar A and Thakur V K 2015 Int. J. Biol. Macromol. 79449

[23] Mishra S, Mohanty A K, Drzal L T, Misra M and Hinrichsen G 2004 Macromol. Mater. Eng. 289955

[24] Sreekumar P A, Saiter J M, Joseph K, Unnikrishnan G and Thomas S 2012 Compos. A, Appl. Sci. Manuf. 43507

[25] Satyanarayana K G, Chand N and Rohatgi P K 1990 in Encyclopedia on composites IV 8 New York

[26] Rowell R M 1998 Sci. Technol. Polym. Adv. Mater. 9869

[27] Haque R, Saxena M, Shit S C and Asokan P 2015 Fibers Polym. 16146

[28] Asokan P, Saxena M, Haque R and Sharma A 2013 Int. J. Eng. Res. Technol. 22914

[29] Asokan P, Firdous M and Sonal W 2012 Rev. Adv. Mater. Sci. 30 254

[30] Asokan P, Osmani M and Price A D F 2009 J. Clean. Prod. 17 821

[31] Saxena M, Morchhale R K, Asokan P and Prasad B K 2008 Compos. Mater. 42367

[32] George J, Sreekalam M S and Thomas S 2001 Polym. Eng. Sci. 411471

[33] Joseph K S, Varghese G, Kalaprasad S, Thomas L, Prasannakumari P and Pavithran C 1996 Eur. Polym. J. 321243

[34] Brouwer WD 2000 SAMPE J. 3618

[35] Kenny J M 2001 Proceedings of the sixth international conference on wood fibre-plastic composites, $\mathrm{p} 9$

[36] Mohanty A K, Misra M and Drzal L T 2002 J. Polym. Environ. 101

[37] Nabi Sahib D and Jog J P 1999 Adv. Polym. Technol. 18 351

[38] Asokan P, Saxena M, Thakur V K, Sharma A and Haque R 2016 J. Macromol. Sci. A, Pure Appl. Chem. 53424 
[39] Idicula M, Neelakantan N R, Ooman Z, Joseph K and Thomas S 2005 J. Appl. Polym. Sci. 961699

[40] Silva R V, Spinelli D, Bose Filho W W, Claro Neto S, Chierice G O and Tarpani J R 2006 Compos. Sci. Technol. 661328
[41] Athijayamani A, Thiruchitrambalam M, Natarajan U and Pazhanivel B 2009 Mater. Sci. Eng. A 517344

[42] Ganguly S, Maity P P, Mondal S, Das P, Bhawal P, Dhara S et al 2019 Mater. Sci. Eng. C 9234 